This item was submitted to Loughborough's Research Repository by the author.

Items in Figshare are protected by copyright, with all rights reserved, unless otherwise indicated.

\title{
Emotional response to food packaging
}

PLEASE CITE THE PUBLISHED VERSION

PUBLISHER

(C) Taylor and Francis

VERSION

AM (Accepted Manuscript)

PUBLISHER STATEMENT

This work is made available according to the conditions of the Creative Commons Attribution-NonCommercialNoDerivatives 4.0 International (CC BY-NC-ND 4.0) licence. Full details of this licence are available at: https://creativecommons.org/licenses/by-nc-nd/4.0/

\section{LICENCE}

CC BY-NC-ND 4.0

\section{REPOSITORY RECORD}

Woodcock, Adrian, George E. Torrens, and D.C. McDonagh. 2019. "Emotional Response to Food Packaging". figshare. https://hdl.handle.net/2134/15761. 


\title{
Emotional response to food packaging
}

\author{
Adrian Woodcock, George Torrens and Deana McDonagh \\ Department of Design and Technology, Loughborough University
}

\section{INTRODUCTION}

This paper describes a pilot study that focused on the perceptions and performance of individuals when opening foodstuff packaging. Demographics are such that the number of people over 65 will increase by $11 \%$ by the year 2011 (National Government Statistics 2002). The needs of this section of the United Kingdom population are not adequately catered for in the design of food packaging. The aim of this study is to highlight the needs, aspirations and emotional response of a sample user group when opening basic packaging.

Food packaging may seem like a purely functional product, but it can have an effect on their own perceptions of how they are coping on a day-to-day basis. Eating and preparing food is an activity of daily living. Being able to perform tasks like these with confidence may lead to elderly people being able to pursue more independent lives with dignity.

To elicit the views and opinions of the more senior people in our society about packaging, a series of discussion groups were held in a residential home near Loughborough University (UK). The information and results obtained helps to refine a larger study assessing the needs and aspirations of elderly and disabled people within our society. This pilot follows on from a study conducted by one of the authors (Torrens et al 2001) in which the forces and postures adopted by participants to open vacuum sealed jam jars were recorded. This pilot study showed that the perceived force was much larger than the 'actual' force required to open the jars. This indicated the main problem areas lay in the prehensile grip of the participants due to the friction between their palmer surfaces of their hands and the packaging. It is thought that peoples perceptions play a major role in the packaging they can open and decide to purchase. Highlighting the importance of the qualitative data supporting the quantitative data, to provide a fuller picture.

Two initial discussion groups of three people, a group of three males and one of three females discussed the issues they perceived as being important when purchasing packaged food. Their physical ability was profiled before opening five types of foodstuff packaging, their performance was recorded on video and through a second interview. The perceived ability or inability of the participants to open packaging and their subsequent success in this task performance will be discussed in relation to the packaging usability and the emotional effect on them. This study attempts to show that food packaging can have an impact on peoples well being and personal esteem. At some time, individuals will have all experienced the frustration and annoyance with our inability to open a tightly sealed jar, regardless of age or physical ability. 
The objectives of this study were to:

- Obtain qualitative information about participants perceptions of foodstuff packaging

- $\quad$ Find through discussion what affects food packaging has on an elderly persons life and emotions

- $\quad$ Observe body language, posture and grip pattern whilst performing task

- Observe and record the emotional response of participants following a task performance

\section{METHOD}

The packaging tested included a) ring pull can; b) plastic welded strip (bacon); c) vacuum sealed jar (jam); d) carbonated drinks bottle (water) and e) foil sealed pack (yoghurt).

Qualitative information about participants perceptions of foodstuff packaging A researcher introduced the topic to the participants with another researcher acting as the scribe. Packaging in general was first discussed to establish any common problems associated with general packaging and to 'get the ball rolling'. Then the packaging to be tested was handed out was discussed individually. The participants highlighted specific issues with each package type and demonstrated problems they perceived when opening that type. The investigators directed the discussion only when it digressed from the focus of the study. The scribe noted important points and comments made by the participants.

\section{Profile the physical characteristics of the participants}

The females were profiled while the males were in the discussion group and vice versa. The profiling included hand measurements (hand length and width measured three times with an anthropmeter). Pinch and grip strengths were also measured, in accordance with previously documented methods (Torrens and Gyi, 1999). These procedures were undertaken to verify that the participants were a relatively representative sample of the elderly population. This data was then compared to the figures in PeopleSize 2000 software (Open Ergonomics 2000).

Observe body language, posture and grip pattern used to perform task

The participants were then seated in front of a video camera and asked to open each type of packaging. The order in which the packaging was presented was different for each participant so that the order of the packaging did not affect the results. Each participant was asked to give the packaging a rating for ease of use and asked questions about their feelings between opening each package. This provided time to rest in order to negate any effects from muscle fatigue and to let the soft tissues in the hand re-inflate (having applied a high pressure to the packaging) due to blood pressure. Participants emotional responses, through visual cues, were noted by the scribe during the interview. These were compared with the body language recorded by the video camera. One female did not complete this stage. 


\section{RESULTS}

\begin{tabular}{|c|c|}
\hline $\begin{array}{l}\text { Packaging cited as being bad or hard to } \\
\text { open: }\end{array}$ & $\begin{array}{l}\text { Packaging cited as being good or easy } \\
\text { to open: }\end{array}$ \\
\hline $\begin{array}{ll}\text { - } & \text { Shrink wrapped products } \\
\text { - } & \text { Jam jars } \\
\text { - } & \text { Products with sticky tape on them } \\
\text { - } & \text { Cornflakes } \\
\text { - } & \text { Ring pulls } \\
\text { - } & \text { Bottle tops }\end{array}$ & $\begin{array}{l}\text { - } \quad \text { Boxed fruit juice cartons, because } \\
\text { the tab is large and easy to hold } \\
\text { Washing powder with large } \\
\text { perforations Pills individually } \\
\text { wrapped (not in bottle) }\end{array}$ \\
\hline $\begin{array}{ll}\text { Emotions expressed } \\
\text { - } & \text { Frustrated } \\
\text { - } & \text { Fed up } \\
\text { - } & \text { Helplessness } \\
\text { - } & \text { Annoyed } \\
\text { - } & \text { Pride }\end{array}$ & $\begin{array}{l}\text { Quotes } \\
\text { "I Struggle when on my own" } \\
\text { "I Loose desire to try" } \\
\text { "Wonderful (if it opens)" } \\
\text { "Makes me frustrated" } \\
\text { "There is no need for it to be difficult" }\end{array}$ \\
\hline $\begin{array}{l}\text { General comments: } \\
\text { "I would not attempt to open it" } \\
\text { "Marvellous when it works" } \\
\text { "It looks easy but I feel bad that I can't } \\
\text { open it" } \\
\text { "I always use a tool to open screw lids", }\end{array}$ & $\begin{array}{l}\text { "Today every thing revolves around the } \\
\text { young who can buy in bulk e.g. buy I get } \\
1 \text { free" } \\
\text { "I am dependant on other people to open } \\
\text { some things" }\end{array}$ \\
\hline
\end{tabular}

\section{Observations}

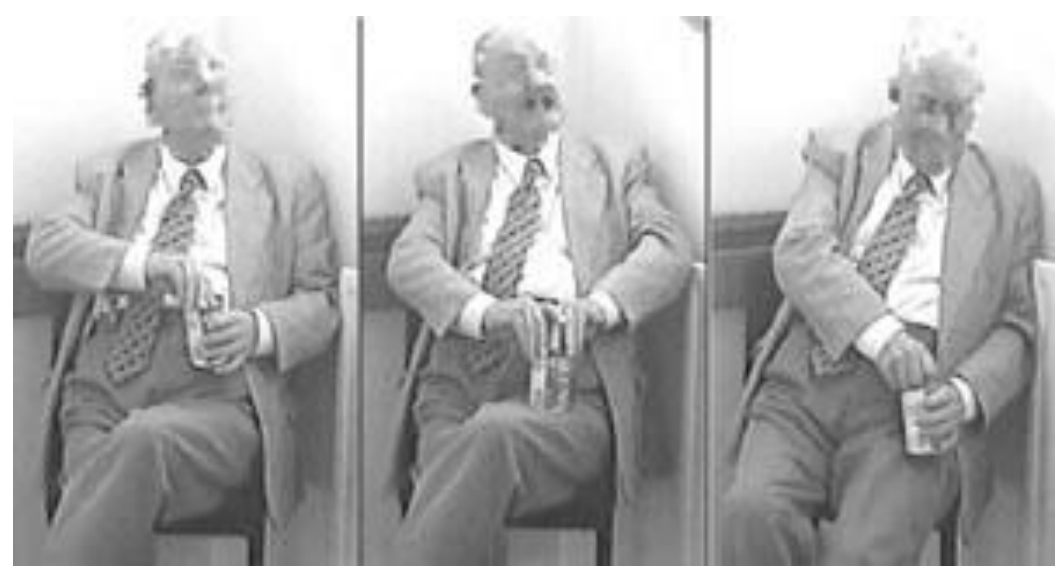

Picture 1 Technique used to open ring pull can.

The participant in picture 1 (above) rated this packaging; 'easy to open'. The observations suggest that this is not the case; at first attempt he cannot lift the ring 
up so he uses both thumbs to prise it up whilst resting it on his thigh, he then uses a power grip to pull the lid off, the recoil spills some of the contents.

\section{DISCUSSION}

The results table summarises the comments made by the participants, the discussion itself gave the researchers a more holistic view of how the participants felt about the packaging. Initially the participants did not explicitly associate food packaging with how they felt but as the discussion progressed the participants shared stories of how they "felt like throwing packaging out of the window". The participants had strong views on how they thought packaging should be. One female participant did not like soap powder boxes, it later emerged that the package was easy to open but the perforations on the cardboard lid made it fall off after opening it a few times. She thought the design was good but badly manufactured, she felt strongly enough about this to buy a different brand. This suggests that opening packaging is not the only cause of frustration for the elderly user, good design and build quality are also important to them.

The male participants were willing to discuss packaging that they felt was bad but were less willing to discuss their emotions when opening packaging. Their body language however did suggest varying degrees of emotion. When some of the participants opened the carbonated drinks bottles they showed surprise and in some cases delight (as can be seen in picture 2, the picture is obscured for participant confidentiality). There was no correlation between participants hand dimension, grip or pinch strength and their ability to open the packaging. A much larger sample size is required to test the significance of this result.

The discrepancy between the observations of the participants body language and their 'easy' ratings is not easily explained (as in picture 1). This may be due to them not wanting to acknowledge that they have a problem, as this would bring into question their independency (as was evident at the beginning of the discussion group with the male participants). It may also be because they have the ability to open it, so they perceive it to be easy, as they cannot open difficult packaging.

A high proportion of the participants stated their preconceptions of the packaging before opening them, some said they would not be able open it before trying to, this is probably due to past experience of similar products (Norman 1998). The majority of participants did not attempt to open the packaging in the way that it was designed. They would seek help or use tool like a knife or even the gap in a door. None of the participants opened all the packaging, none could open the bacon, and two of the five did not know that it was possible or even designed to be opened by the tab in the corner. The package instructions caused much discussion, the 'tamper evident' button caused confusion, also some of the instructions were 'not helpful' and were perceived as 'irritating'. An example of the instruction that caused irritation was "Instructions: open by hand".

All the participants lived in a residential home with a home manager available on site if necessary. The participants said their choice of food was affected by the packaging i.e. they purchased loose bacon and if they live on their own they would worry about their ability to open the packaging. Some would only purchase certain food when they had younger or able visitors, not to entertain them but so that they could have the packaging opened for them. 


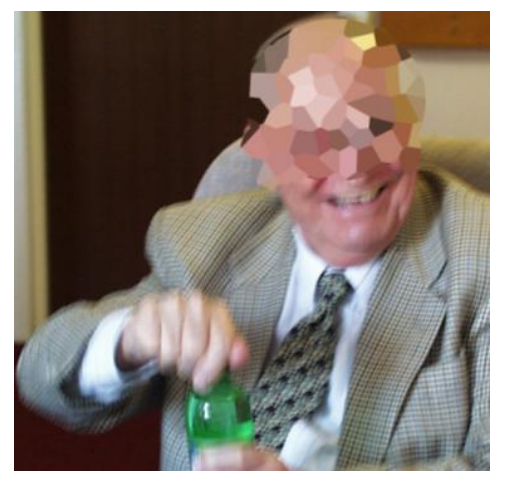

Picture 2 Participant showing his reaction at being able to open a carbonated drinks bottle after saying; "packaging does not change how I feel".

\section{CONCLUSIONS}

- Perceptions people have of packaging means that they do not attempt to open them therefore they do not purchase them.

- Food packaging can have a positive or negative affect on a person's feelings.

- Good packaging can enhance and contribute less able people in leading independent lives and therefore maintain their self esteem and dignity.

- The emotion participants suggested via their body language differed from the emotion they stated in questionnaire.

- The participants hand strength seems enough to open the packaging but they cannot apply this to the packaging due to the product semantics and surface features.

- A larger more comprehensive study will be carried out to explore these issues further.

\section{REFERENCES}

Donald N.A, The design of everyday things. London: MIT Press 1998

National Government Statistics <http://www.statistics.gov.uk/statbase/mainmenu.asp> (10 April 2002)

People Size version 2.0.Open Ergonomics Ltd. 2000. www.openerg.com (10 April 2002)

Torrens G.E. and Gyi D., 1999, Towards the integrated measurement of hand and object interaction. 7th International Conference on Product Safety Research, European Consumer Safety Association, U.S. (Consumer Product Safety Commission, Washington D.C.), 217-226

Torrens G.E, Williams, G. and Huxley, R. 2001, "Could you open this jar for me please": A pilot study of the physical nature of jar opening. Contemporary Ergonomics 200. London: Taylor \& Francis 2000. pp73 